\title{
Managing cool-season turfgrass without herbicides: Optimizing maintenance practices to control weeds
}

\author{
Rossana Sallenave $^{2}$ (1) | Cristina Pornaro $^{3}$ \\ Bernd Leinauer $^{1}$ (])
}

\begin{abstract}
${ }^{1}$ Department of Plant Sciences, Centre for Crop Systems Analysis, Wageningen University, Wageningen, The Netherlands

2 Department of Extension Animal Sciences and Natural Resources, New Mexico State University, Las Cruces, NM, USA

${ }^{3}$ Department of Agronomy, Food, Natural Resources, Animals, and Environment, University of Padova, Padova, ITALY

\section{Correspondence}

Bernd Leinauer, Department of Plant Sciences, Centre for Crop Systems Analysis, Wageningen University, Wageningen, The Netherlands.

Email: bernd.leinauer@wur.nl
\end{abstract}

Assigned to Associate Editor Benjamin Wherley.

\begin{abstract}
Bans on the use of synthetic herbicides require innovative management approaches to maintain the attractiveness and usability of turfgrass swards. Such measures should include the use of locally adapted cultivars that germinate and establish quickly, resulting in the densest possible stands. Additionally, a number of turfgrasses have been reported to produce allelopathic substances that inhibit common turfgrass weeds. Mowing heights should be set to achieve maximum weed suppression while still providing acceptable quality for desired use. Sustainable turfgrass management programs have led to a reduction in fertilizer inputs; however, without the availability of herbicides, fertilization regimes need to be re-examined. The literature suggests that broadleaf weeds are reduced but never fully controlled when more $\mathrm{N}$ is applied; therefore, finding a balance between what is needed and what is environmentally safe and sustainable is critical. Organic herbicides include plant pathogens from the fungus Phoma and strains of the bacterium Pseudomonas fluorescens. Both can be used to control several weeds common to turfgrasses. Acetic acid has also been shown to have herbicidal activity; however, it has limited residual activity, and its efficacy remains questionable on mature weeds. Thermal weed control can be used to sterilize a seedbank or spot treat existing weeds. Future turfgrass breeding programs could focus on understanding and enhancing the allelopathic potential of turfgrasses to outcompete weeds more effectively. Furthermore, more research should be directed at assessing the competitiveness of certain turfgrasses against weeds within the limitations of producing turfgrass areas of acceptable aesthetics and playing quality.
\end{abstract}

\section{1 | INTRODUCTION}

Weeds are plants that are defined as undesirable in a specified area because of their ability to compete with native or desirable plant species (McCarty, Murphy, \&
Turgeon, 1994). Turfgrasses compete with weeds for nutrients, water and space below ground (Snaydon, 1971), and for light above ground (Holt, 1995). Moreover, the presence of weed species in turfgrasses reduces playing quality, aesthetic value, and usability (Larsen, Kristoffersen, \& 
Fischer, 2004; McCarty et al., 1994; McElroy \& Martins, 2013; Stewart-Wade, Neumann, Collins, \& Boland, 2002). Weed species rapidly germinate in exposed soil (McElroy \& Martins, 2013) caused by abiotic factors, such as vehicular or human wear, drought, shade, cold, as well as by biotic factors affecting turfgrasses such as pest and disease damage (Brodie \& Burton, 1967; Busey, Broschat, \& Center, 1982; Waddington, T.R., J.M., \& Moberg, 1978). Established weed species have a lower wear tolerance compared with turfgrasses, which increases the risk of soil exposure on weed infested turfgrass areas (McElroy \& Martins, 2013). In terms of their aesthetic appearance, weeds often stand out because of enhanced floral production or color differences vs. turfgrass (McCarty et al., 1994). Additionally, some turfgrass weed species, such as dandelion (Taraxacum officinale F. H. Wigg) and white clover (Trifolium repens L.), are too close to the soil to be removed by mowing and produce patches that disrupt uniformity and affect ball roll and lie in sports scenarios (Larsen et al., 2004).

Turfgrass areas infested with weeds are often considered a sign of mismanagement (Masin, Zuin, Archer, Forcella, \& Zanin, 2005); however, weeds can establish even under optimal management (Busey, 2003). Nevertheless, weeds establish opportunistically if managers fail to reduce overall weed densities to a minimum and maintain a dense turfgrass sward.

Herbicides are the predominant method to control weeds in turfgrass management particularly in large areas such as golf course fairways (Dahl-Jensen, Norman Petersen, \& Aamlid, 2014). No new herbicide mechanism of action (MOA) has been discovered since the 1980s, and an ever-increasing risk of herbicidal resistance could lead to virtually complete resistance to all conventional mechanisms of action by 2050 (Westwood et al., 2018). In 2017, the Weed Science Society of America listed > 300 commercially sold modes of action to control weeds in agriculture and turfgrass (Weed Science Society of America, 2017). The use of herbicides in the United States golf industry increased by an average of 2\% between 2007 and 2015 (Golf Course Superintendents Association of America, 2017) with regional differences; for example, golf courses located in transition zones increased herbicide use by $13 \%$ whereas north-central regions reduced use by $8 \%$ (Golf Course Superintendents Association of America, 2017).

In the European Union, much stricter bans on herbicides have been established. The risk of herbicide resistance (De Prado \& Franco, 2004; Heap, 1997), health risks associated with herbicide exposure (Karabelas, Plakas, Solomou, Drossou, \& Sarigiannis, 2009), and environmental concerns (Stoate et al., 2009) have led to a restriction of synthetic herbicide products (Barzman \& DachbrodtSaaydeh, 2011). Today, only 123 herbicides are approved for commercial use (European Commission, 2017), and strict bans have been introduced in the turfgrass sector. For example, in Germany, only two herbicides, namely Banvel $\mathrm{M}$ and Nasalt (active ingredients Dicamba and MCPA, respectively), can be used on golf courses (German Golf Association, 2017). In Great Britain, the maximum allowable overall load of herbicide active ingredients that may be applied to amenity turfgrass (public areas, residential lawns, sports field, golf courses, etc.) was reduced from $1837 \mathrm{t}$ in 2006 to $671 \mathrm{t}$ in 2012, a 64\% reduction (Department for Environment, Food and Rural Affairs, 2015). Denmark has set maximum permitted levels of pesticide use for designated areas on golf courses (European Commission, 2017). This has resulted in an $82.7 \%$ decrease in annual pesticide use on golf courses from 1998 to 2014 (T. K. Petersen, personal communication, 2018). In Holland, the turfgrass industry has agreed to accept a complete ban of all pesticides by 2020 (Government of the Netherlands, 2017).

It is clear that the future of weed control in European turfgrass landscapes will be limited to nonchemical herbicide strategies. Few studies, other than those of DahlJensen et al. (2014) and Silvertown et al. (2006), have investigated nonchemical management practices for weed suppression in amenity turfgrasses. In Scandinavia, most golf courses can cope with herbicide-free management but Dahl-Jensen et al. (2014) found that weed densities severely increased after a period of $\sim 3 \mathrm{yr}$. Weed control is most effective under such circumstances when a variety of methods are used to support the growth of desirable species and reduce the fitness of unwanted weed species (Marble, Koeser, \& Hasing, 2015).

Weeds are early colonizers and their persistence is dependent on their competitive ability against turfgrasses (Watschke, Dernoeden, \& Shetlar, 1995). Nonchemical approaches to control weeds must therefore focus on reducing the availability of ecological niches in a turfgrass sward for weed colonization, germination, and establishment (Larsen et al., 2004). Maintaining dense turfgrass swards is primarily dependent on the genetic ability of turfgrasses to resist local abiotic and biotic stresses (Watschke \& Engel, 1994). Secondly, maintenance practices aimed at promoting turfgrass growth favor the competitive ability of turfgrasses to outcompete weeds (Dahl-Jensen et al., 2014). The following sections provide a perspective on amenity turfgrass management approaches focused on weed control without the use of herbicides.

\section{2 | TURFGRASS SELECTION}

Cultivars that germinate and establish quickly should be selected in newly seeded areas to reduce the chances of weed germination. The selected cultivars need to be adapted to the local climate to provide the densest turfgrass 
sward possible. Every year, the British Society of Plant Breeders (https://www.bspb.co.uk/\#) Turfgrass Seed manual (British Society of Plant Breeders, 2020) and the National Turfgrass Evaluation Program (https://www. ntep.org) rank the majority of turfgrass cultivars for different characteristics such as visual merit, shoot density, live ground cover, resistance to abiotic and biotic stress, fineness of leaf, cleanness of cutting, disease resistance, color, and recovery. This allows turfgrass managers to select turfgrass cultivars that establish and become dense quickly for outcompeting weeds in seeded areas.

Selecting turfgrasses for resistance against local biotic (e.g. insects, diseases etc.) stresses can have a secondary effect on weed establishment over time (Busey, 2003). Davis (1958) recorded an outbreak of leaf blight [Dreschlera poae (Baudys) Shoemaker] in Kentucky bluegrass (Poa pratensis L.) that caused an outbreak of broadleaf weeds infestation. Waddington et al. (1978) attributed annual bluegrass (Poa annua L.) invasion in creeping bentgrass [Agrostis stolonifera L. var. palustris (Huds.) Farw.] swards to injury after dollar spot (Sclerotinia homoeocarpa) outbreaks. Brodie and Burton (1967) found a reduction in density of 'Tifgreen' [Cynodon dactylon (L.) Pers. $\times$ C. transvaalensis Burtt-Davy] under nematodes (Belonolaimus longicaudatus Rau) infestation and increased establishment of spotted spurge \{Euphorbia maculata L. [三 Chamaesyce maculata (L.) Small]\} (Brodie \& Burton, 1967).

Besides biotic stresses, abiotic stresses (e.g. drought, infertility etc.) can also increase weed densities in turfgrass swards. Perennial ryegrass (Lolium perenne L.) showed susceptibility to colonization by spotted spurge under reduced irrigation (Gibeault, Meyer, \& Youngner, 1985). In a trial for which 'Big Horn' blue fescue \{Festuca glauca Vill. [三 F. ovina var. glauca (Vill.) W. D. J. Koch]) and 'Aurora' hard fescue [F. trachyphylla (Hack.) R. P. Murray] were kept without fertilizer and irrigation, the turfgrasses showed superior resistance to smooth crabgrass [Digitaria ischaemum (Schreb.) Schreb. ex Muhl.] and white clover infestation vs. tall fescue (Lolium arundinaceum (Schreb.) S.J. Darbyshire) cultivars (Dernoeden, Carroll, \& Krouse, 1994). The authors also found that tall fescue cultivars were poorer competitors against weeds under low cutting regimes vs. blue fescue and hard fescue.

Competitive growth studies between monocultures and cultivars in mixtures may provide insight into potential weed suppressing characteristics. In cool-season turfgrasses, a mixture of turfgrasses under low-maintenance regimes is generally more effective in controlling weeds than a single species sward (McKernan, Ross, \& Tompkins, 2001). Mixtures of Kentucky bluegrass and perennial ryegrass achieved $8 \%$ higher leaf area index than monocultures of each single species, which may explain the supe- rior weed suppression characteristics of such mixtures (Brede \& Duich, 1984). Moreover, cultural management practices can be adjusted to favor certain species; however, dominance is a combination of the genotype and the environment. For example, long-leafed perennial ryegrass is dominant over short-leafed perennial ryegrass genotypes under infrequent cutting because long-leafed genotypes are better competitors for light (Hazard \& Ghesquiere, 1995). Kentucky bluegrass can dominate over creeping red fescue (F. rubra L. subsp. rubra) at high levels of nitrogen (N) input, whereas creeping red fescue dominates at low levels of N (Juska, Tyson, \& Harrison, 1955). At low temperatures, mixtures of red fescue [Festuca rubra L. subsp. litoralis (G. Mey.) Auquier] and perennial ryegrass are capable of germinating more quickly than other species, potentially increasing their competitive ability over weeds (Larsen \& Bibby, 2005). In mixtures of creeping bentgrass, red fescue, and Kentucky bluegrass, the creeping bentgrass dominated when the turfgrass was maintained at close mowing heights (Davis, 1958).

A common approach in turfgrass management is to encourage the growth of turfgrasses requiring less inputs of valuable resources, which is critical for a sustainable management approach (Cisar, 2004). However, encouraging the use of low-input species is only one aspect of sustainability. The most sustainable turfgrass species are those that provide the best performance for desired use yearround as well as being adapted to local pest, disease, and weed problems.

\section{3 | SEEDING AND OVERSEEDING STRATEGIES}

The choice of a proper seeding rate as well as the use of overseeding to increase turfgrass densities can provide a competitive edge over weeds (Parr, 1985). The benefits of planting newly constructed areas with higher than recommended seeding rates to suppress weeds have been reported. For example, Beard, Martin, and Mercer (1980) showed that seeding Kentucky bluegrass at $90 \mathrm{~kg} \mathrm{ha}^{-1}$, instead of $45 \mathrm{~kg} \mathrm{ha}^{-1}$, reduced weed cover on average by $21 \% 2$ mo after seeding.

Overseeding strategies can successfully reduce weed populations if sufficient seed germination is achieved (Aamlid, 1992; Begon, Harper, \& Townshend, 1996; Larsen \& Fischer, 2005; Larsen et al., 2004). Harris (2008) found that overseeding at seeding rates ranging between $12.5 \mathrm{~g} \mathrm{~m}^{-2}$ and $100 \mathrm{~g} \mathrm{~m}^{-2}$ all provided denser swards with fewer weeds than not overseeding if seeds successfully germinated. Overseeding can be integrated as a regular practice to increase the competitiveness of turfgrasses. Best practices to increase germination after overseeding 
and reduced weed pressure include overseeding during reduced weed growth, providing good seed-soil contact, and following a fertilizer regime (Vargas \& Turgeon, 2004). During germination, sufficient phosphorous $(\mathrm{P})$ must be present, whereas after establishment, $\mathrm{N}$ is required to facilitate shoot and root growth (Christians, 2016; McVey, 1968).

Proper species selection for overseeding purposes is also crucial. Perennial ryegrass showed good germination rates regardless of whether or not water and fertilizer were applied (Dahl-Jensen, Bühler, Kvalbein, \& Aamlid, 2017; Elford, Tardif, Robinson, \& Lyons, 2008). Additionally, perennial ryegrass germinates quickly and has good root and shoot competition against weeds (Haugland \& FroudWilliams, 1999). Quick and successful establishment is important to outcompete weed seedlings for light and fertilizer (Jeangros \& Noesberger, 1990; Snaydon and Howe, 1986). Frequent overseeding with high rates of perennial ryegrass appears to provide competition against perennial weeds over the short term when weed cover is high and should be considered an important part of a weed management program for municipal turfgrass managers (Elford et al., 2008). Increasing overseeding rates in existing swards could be a long-term weed management strategy. The effect of overseeding might be especially noticeable on sparse turfgrass swards (Dahl-Jensen et al., 2014; Nyholt, 2010).

Another approach to aid turfgrass establishment in newly constructed and seeded areas is to use amendments. Products include Turfiber, alfalfa hay, oat straw, straw mulch, mat seeding, hydro mulch, and other materials. These products increase moisture retention in the soil and suppress weed germination (Barkley, Blaser, \& Schmidt, 1965; Hansford, 1981; Hensler, Baldwin, \& Goatley, 2001; Shearman, Steinegger, Kinbacher, \& Riordan, 1979; Sowers \& Welterlen, 1988). Emphasis must be placed on increasing germination success after overseeding using adequate machinery to place seeds at the right soil depth, provide uniform irrigation coverage, and provide adequate fertilization.

\section{4 | ALLELOPATHIC POTENTIAL}

The biological phenomenon of allelopathy has been effectively used in agriculture by producers to suppress weeds (Jabran, Mahajan, Sardana, \& Chauhan, 2015). The capacity of turfgrasses to produce allelopathic substances that influence weed invasion has been reported for a variety of turfgrasses. Turfgrass roots are capable of preventing root invasion from competitor plants by producing leachates that can modify the soil matrix or lead to toxicity after absorption by competitor plants (Seigler, 2006). Thus, allelopathy can be described as a competition mech- anism that could provide some control of weed species in turfgrass areas.

The application of aqueous leachates derived from perennial ryegrass, red fescue, and Kentucky bluegrass to rooted cuttings of forsythia (Forsythia Xintermedia Zabel) reduced top growth of this woody plant (Fales \& Wakefield, 1981). Perennial ryegrass showed allelopathic potential on clover, which was enhanced by crown rust (Puccinia coronate Corda f. sp. lolii Brown) infection of perennial ryegrass (Mattner \& Parbery, 2001). Understanding the mechanisms of such interactions could lead to their improved effectiveness in the field and to the isolation of allelopathic compounds for biological herbicide formulations.

Peters and Luu (1985) observed tall fescue pastures free of other plant species and attributed the absence of other plants to the allelopathic potential of tall fescue. In bioassay trials, tall fescue exudates reduced seedling growth of rape (Brassica napus L.), birdsfoot trefoil (Lotus corniculatus L.), red clover (Trifolium pratense L.), and several other common turfgrass weeds (Luu, Matches, \& Peters, 1982; Peters \& Zam, 1981; Rice, 1987). Clippings of creeping red fescue and colonial bentgrass (Agrostis capillaris L., [= Agrostis tenuis Sibth.]) reduced germination and early growth of white clover in container studies conducted by Norrington-Davies and Buckeridge (1994). Bertin, Senesac, Rossi, DiTommaso, and Weston (2009) showed that weed suppression varied greatly among fescue cultivars. They found strong creeping red fescue cultivars and Chewings fescue cultivars to be most effective at weed suppression.

Allelopathy based breeding programs could be developed to select for allelopathic turfgrass varieties. A future approach might be to develop biological plant protection products from phytotoxic exudates. Putative compounds could be isolated from a methanol extract of root material, and the chemical structure could be determined by highresolution mass spectrometry, infrared spectroscopy, and hydrogen-1 nuclear magnetic resonance (Kato-Noguchi, 2003). Once allelopathic cultivars or species demonstrating strong competitiveness against weeds are identified, turfgrass managers should consider establishing these species over time.

\section{5 | ADJUSTING MOWING PRACTICES AND FERTILIZATION TO INCREASE COMPETITIVENESS OF TURFGRASS SPECIES}

Mowing heights should be adjusted to a point where the turfgrass canopy becomes dense enough to suppress weed populations and short enough to provide good playing conditions. Cutting heights of turfgrasses can be adjusted throughout the year to stimulate either above- or 
belowground growth. The same applies to fertilization applications. Fertilization can lead to quick or slow growth depending on the type of fertilizer being used. Fertilization can encourage above- or belowground growth, depending on the application method, timing, and type of fertilizer. Practices such as aeration can generally increase infiltration rates, rooting depth, and turfgrass health.

\subsection{Mowing practices}

Increasing mowing frequency of turfgrasses results in less root mass, rhizome, and stolon production but increased shoot density (Hull, 2000). The effect of mowing height on turfgrass weeds, such as crabgrass (Digitaria spp.), is well documented (Busey, 2003). Raising cutting heights has been found to reduce crabgrass densities over time in Chewings fescue (F. rubra spp.) (Jagschitz \& Ebdon, 1985), Kentucky bluegrass (Dunn, Nelson, \& Winfrey, 1981; Niehaus, 1974), tall fescue (Dernoeden, Carroll, \& Krouse, 1993; Hall, 1980; Voigt, Fermanian, \& Haley, 2001), and fine fescue species (Dernoeden, Fidanza, \& Krouse, 1998). Using variable mowing heights throughout the season had no effect on controlling crabgrass in tall fescue (Cropper, Munshaw, \& Barrett, 2017). Therefore, using a consistently high mowing height might be most effective to increase competitiveness of turfgrasses against crabgrass.

Adams (1980) showed that annual bluegrass cover, in a perennial ryegrass dominated sward, decreased from 34 to $9 \%$ when the cutting height was raised from 1.25 to $7.5 \mathrm{~cm}$. However, few studies exist that have investigated the relationship between mowing height and broadleaf weed densities. Fine fescue was reported to be more competitive over a mixture of broadleaf weeds (e.g. dandelion, white clover, crabgrass) when the mowing height was raised from 1.9 to $5.1 \mathrm{~cm}$ (Davis, 1958). Gray and Call (1993) found that raising the mowing height to $6 \mathrm{~cm}$ in tall fescue dominated turfgrass was successful in reducing common blue violet (Viola sororia Willd).

Studies suggest that weed densities can generally be reduced but never fully controlled with only mowing and fertilization (Busey, 2003). The extent to which overall weed densities can be lowered is also dependent on the competitive ability of the turfgrass species composition. In a trial with different mowing heights, fertilizer rates, and turfgrass species, DeBels, Griffith, Kreuser, Melby, and Soldat (2012) found 'Kenblue' Kentucky bluegrass had the highest weed encroachment regardless of fertilizer or mowing treatment.

Raising cutting heights usually increases competitiveness of desirable turfgrasses; however, it is unclear if small changes within the limitations of usability has an effect on weed pressure. For example, golf fairways are usually maintained at heights ranging from 8 to $25 \mathrm{~mm}$, but there are no studies that have examined whether a high over a low cutting height provides superior weed control. Common sense suggests that turfgrass should be kept as dense as possible throughout the year, hence, cutting heights should be increased if turfgrass is sparse but can be lowered if turfgrass remains sufficiently dense. Furthermore, mowing height and frequency are dependent on the growth rate of the turfgrass. Factors that influence growth rates include genotype, climate, the growth medium, and the management input of water and fertilizer. Therefore, it seems unlikely that weed pressure will be reduced by small changes in cutting height alone.

\section{2 | Handling of clippings}

Returning clippings to turfgrasses is thought to increase soil levels of carbon and $\mathrm{N}$ if microbial activity is sufficient to mineralize $\mathrm{N}$ (Haley, Wehner, Fermanian, \& Turgeon, 1985; Law, Trappe, Jiang, Turco, \& Patton, 2017; Macdonald, Powlson, Poulton, \& Jenkinson, 1989; Qian et al., 2003; Shepherd, Stockdale, Powlson, \& Jarvis, 1996; Starr \& DeRoo, 1981). Knot et al. (2017) and Qian et al. (2003) applied the century model and calculated that returning clippings can reduce a turfgrasses $\mathrm{N}$ requirement by $25 \%$ if it is $1-10 \mathrm{yr}$ old, by $33 \%$ if it is $11-25 \mathrm{yr}$ old, and $>50 \%$ if it is older than 25 yr. However, since additional nutrients can also be provided by increasing fertilizer rates, the decision to remove clippings is based more on aesthetic or financial considerations. The positive effects of returning nutrients derived from clippings to the system can be offset by the addition of weed seeds (Heckman, Liu, Hill, DeMilia, \& Anastasia, 2000). Weedrelated negative effects of returning clippings have been especially observed with annual weeds, which survive by producing large numbers of seeds. Clipping removal led to a $60 \%$ reduction of viable annual bluegrass seeds in a bentgrass dominated turfgrass sward (Gaussoin \& Branham, 1989). Therefore, if the turfgrass sward is dominated by unwanted annual bluegrass, clippings removal should be considered to reduce the seedbank build up.

In contrast, clippings can contain allelochemical compounds, which have herbicidal activity (Akbari, Sajedi, Gomarian, \& Akbari, 2015). Bertin, Yang, and Weston (2003) and Wu, Harivandi, and Guo (2002) conducted studies in which these compounds were isolated and tested in pot and petri dish experiments. Allelopathic compounds isolated from a mixture of perennial ryegrass, Kentucky bluegrass, and particularly red fescue inhibited germination and seedling growth of prostrate pigweed (Amaranthus blitoides S. Watson) (Akbari et al., 2015). It is unclear if simply returning clippings after mowing has 
an allelopathic-based inhibitory effect on weeds, as allelopathic compounds interact with soil physical and chemical parameters, climate, and other biotic factors such as microbial activity (Wu et al., 2002), all of which can influence allelopathic efficacy.

\section{$5.3 \mid$ Fertilization}

Fertilization changes botanical composition and reduces species richness through competitive exclusion but increases biomass in plant communities (DiTommaso \& Aarssen, 1989; Gough, Osenberg, Gross, \& Collins, 2000, Grime, 1973; Templeton \& Taylor, 1966). For example, tees, fairways, and greens are ideally dominated by only a few desirable turfgrass species to produce high quality surfaces (Bridges, 1994). Consequently, fertilization is a powerful tool to encourage dominance of desirable turfgrass species. In the absence of herbicides, turfgrass managers may need to re-examine some traditional cultural practices that have fallen out of favor in recent times because of budget constraints and environmental concerns. In particular, increased fertilization rates that have been shown to provide competitive edges to turfgrasses over weeds are now discouraged because of fertilizer costs, risk of groundwater leaching of nitrate, as well as surface runoff of excess fertilizer into receiving water bodies that lead to algal blooms among other things.

Nitrogen is the most limiting nutrient for plant growth (Bowman, Theodose, Schardt, \& Conant, 1993). In aerated soils, plants acquire $\mathrm{N}$ mainly through inorganic forms of nitrate $\left(\mathrm{NO}^{3-}\right)$ and ammonium $\left(\mathrm{NH}^{4+}\right)$. Availability of $\mathrm{N}$ is subject to biotic and abiotic processes affecting the total pool of soil $\mathrm{N}$. Minor portions of $\mathrm{N}$ are utilized in organic forms, that is, amines and amino acids (Devienne-Barret, Justes, Machet, \& Mary, 2000; Lipson, Raab, Schmidt, \& Monson, 2001). Application of $\mathrm{N}$ to grassland systems changes the competitive ability of turfgrasses against weeds (Silvertown, 1987; Silvertown et al., 2006). Calhoun, Rinehart, Hathaway, and Buhler (2005) reported that applying $\mathrm{N}$ to a mixture of Kentucky bluegrass, perennial ryegrass, and red fescue at a rate of 150 $\mathrm{kg} \mathrm{ha}^{-1} \mathrm{yr}^{-1}$ reduced white clover density by $61-88 \%$ in a 4 -yr study period. White clover was significantly reduced in tall fescue pastures when $135 \mathrm{~kg} \mathrm{~N} \mathrm{ha}^{-1} \mathrm{yr}^{-1}$ was applied (Rajaniemi, 2002). A turfgrass sward dominated by Kentucky bluegrass maintained with $196 \mathrm{~kg} \mathrm{ha}^{-1} \mathrm{yr}^{-1}$ of $\mathrm{N}$ exhibited better visual turfgrass quality with lower weed densities than plots receiving no fertilizer (DeBels et al., 2012). Studies of Kentucky bluegrass, tall fescue, and Chewings fescue turfgrass swards showed that higher rates of $\mathrm{N}$ fertilizer reduced crabgrass densities significantly but did not result in full weed control (Dernoeden et al., 1993; Dunn et al., 1981; Jagschitz \& Ebdon, 1985; Johnson, 1981; Johnson \& Bowyer, 1982; Murray, Klingman, Nash, \& Woolson, 1983; Voigt et al., 2001). Johnson and Bowyer (1982) reported that Kentucky bluegrass plots receiving 300 and $600 \mathrm{~kg} \mathrm{~N} \mathrm{ha}^{-1} \mathrm{yr}^{-1}$ had lower dandelion densities ( $\sim 30$ and $<10 \%$, respectively) than plots that were not fertilized ( $40 \%$ dandelions). Other studies in which broadleaf weed composition was not given reported minimal weed densities when $300 \mathrm{~kg} \mathrm{~N} \mathrm{ha}^{-1} \mathrm{yr}^{-1}$ was applied to Kentucky bluegrass- or tall fescue-dominated turfgrass swards (Haley et al., 1985; Voigt et al., 2001). The literature suggests that broadleaf weeds are reduced when more $\mathrm{N}$ is applied, therefore, finding a balance between what is needed and what is environmentally safe and sustainable is critical.

Established turfgrass that is not over irrigated loses on average $<5 \%$ of the $\mathrm{N}$ applied when rates of $200-300 \mathrm{~kg}$ $\mathrm{N} \mathrm{ha}^{-1} \mathrm{yr}^{-1}$ are used (Barton \& Colmer, 2006). Therefore, maintaining annual application rates of total $\mathrm{N}$ to turfgrass below the upper threshold of $300 \mathrm{~kg} \mathrm{~N} \mathrm{ha}^{-1} \mathrm{yr}^{-1}$ could be recommended. Such a high rate of $\mathrm{N}$ is rarely applied to any turfgrass area, hence, if sensible turfgrass management approaches are used, such as frequent, low doses of $\mathrm{N}$, the risk of environmental pollution of surface and groundwater is minimized, and the benefits of outcompeting weeds are maximized.

Unfortunately, $\mathrm{N}$ fertilization has also been shown to increase production of annual bluegrass, which outcompetes desirable turfgrass species (Dest \& Guillard, 1987; Lodge \& Lawson, 1993). Such a transition is a concern for turfgrass managers. Nam-Il, Ogsasawara, Yoneyama, and Takeuchi (2001) reported that annual bluegrass only requires $300 \mathrm{mg} \mathrm{kg}^{-1} \mathrm{~N}$ compared with bentgrass (1000 mg $\mathrm{kg}^{-1} \mathrm{~N}$ ) to produce maximum shoot and root growth in a greenhouse study. Growth of both species, particularly root growth, is very responsive to $\mathrm{N}$ and to a lesser extent to $\mathrm{P}$ and potassium (K) levels (Nam-Il et al., 2001). However, the competitive advantage of annual bluegrass over other turfgrass species in $\mathrm{N}$ fertilizer trials is not conclusive. A minimal increase of $12-17 \%$ in annual bluegrass cover was observed in perennial ryegrass dominated turfgrass when $\mathrm{N}$ rates were increased from 0 to $352 \mathrm{~kg} \mathrm{~N} \mathrm{ha}^{-1} \mathrm{yr}^{-1}$ (Adams, 1980). Gaussoin and Branham (1989) observed an increase in annual bluegrass cover in $1 \mathrm{yr}$ out of three when $293 \mathrm{~kg} \mathrm{~N} \mathrm{ha}^{-1} \mathrm{yr}^{-1}$ was applied to a mixture of annual bluegrass and creeping bentgrass instead of $98 \mathrm{~kg} \mathrm{~N} \mathrm{ha}^{-1} \mathrm{yr}^{-1}$. In contrast, Calvache et al. (2017) reported that changing $\mathrm{N}$ or $\mathrm{P}$ fertilizer rates had no effect on annual bluegrass densities in bentgrass- and fescue-dominated golf greens. The effect of $\mathrm{N}$ rates on the competitive ability of annual bluegrass might differ because of differences in soil type, category of fertilizer, method of application, or soil $\mathrm{pH}$. For example, in a bentgrass and annual bluegrass mixture, 
foliar application of $\mathrm{N}$ favors annual bluegrass growth, whereas granular applications increase bentgrass growth (O'Connor, Hébert, Powers, Jordan, \& Lyons, 2018). Moreover, Lodge and Lawson (1993) reported that a stepwise increase in $\mathrm{pH}$ from 4.5 to 5.5, through the application of lime for $1 \mathrm{yr}$, considerably increased annual bluegrass cover from 0 to $30 \%$ in a fescue-bentgrass dominated golf green.

For turfgrass managers, it is often difficult to estimate minimum levels of $\mathrm{N}$ required to provide a turfgrass with a competitive edge over weeds. The approach used by agricultural producers could be followed in such cases. The critical $\mathrm{N}$ amount in agriculture is defined as the minimum concentration needed to achieve maximum plant growth. As plants mature, critical N concentrations decrease (Gastal \& Lemaire, 2002). Turfgrass managers should focus on limiting $\mathrm{N}$ applications to minimum amounts needed to produce an acceptable level of playing quality or aesthetic appeal. Acceptable playing quality or aesthetic appeal can be measured objectively or defined by a combination of factors such as human expectations, budget limitations, and ecological considerations.

As the addition of $\mathrm{N}$ influences the competitive ability of turfgrasses over weeds, the dose and type of other nutrients added to a turfgrass area also influence turfgrass species composition. In a long-term parkland study, legumes established better in plots fertilized with $\mathrm{P}$ and $\mathrm{K}$ ( $>30 \%$ of ground cover), while turfgrasses dominated in plots fertilized with $\mathrm{N}$ ( $\sim 90 \%$ of ground cover) (Silvertown, 1987; Silvertown et al., 2006). Phosphorous and $\mathrm{K}$ fertilizer applied consistently at high rates favored annual bluegrass invasion into bentgrass swards (Goss, Brauen, \& Orton, 1975; Kuo, 1993a; Waddington et al., 1978). In low-P soils that are acidic, bentgrass was found to outcompete annual bluegrass because it was more efficient at absorbing P under those conditions (Kuo, Brauen, \& Jellum, 1992). Consequently, macronutrients, such as $\mathrm{P}$ and $\mathrm{K}$, should only be applied if soil levels are low because annual bluegrass and broadleaf weeds such as dandelion are better competitors when soil levels of these minerals are high.

Other strategies to outcompete annual bluegrass include the application of sulfur to acidify the soil and the reduction of N applications (Dest \& Guillard, 1987; Goss et al., 1975). High levels of sulfur (168 $\mathrm{kg} \mathrm{S} \mathrm{ha}^{-1} \mathrm{yr}^{-1}$ ) lowered the $\mathrm{pH}$ of the soil, which in turn reduced $\mathrm{P}$ availability and annual bluegrass densities in creeping bentgrass swards (Goss, 1974). Broadleaf weeds become somewhat less competitive when soil $\mathrm{pH}$ is lowered; this could potentially be achieved by the application of iron. Also, lowering the soil $\mathrm{pH}$ with long-term applications of ammonium sulfate led to reduced broadleaf weed populations and in some cases to weed-free turfgrass (Escrit \& Lidgate, 1964; Thompson, Clarke, \& Heckman, 1995). In acidic soils, the application of calcium favors bentgrass growth over annual bluegrass
(Kuo, 1993b). Furthermore, applying $1.68 \mathrm{~kg} \mathrm{ha}^{-1} \mathrm{yr}^{-1}$ of both iron and magnesium to bentgrass has been shown to suppress annual bluegrass by $65 \%$ (Bell, Odorizzi, \& Danneberger, 1999); however, the $\mathrm{pH}$ must be maintained at an optimum level for turfgrass growth to maintain competitiveness.

Fertilization may not only affect growth of desired turfgrasses but can also benefit broadleaf weeds in a stand. Dodd, Silvertown, McConway, Potts, and Crawley (1994) and Tilman, Tilman, Crawley, and Johnston (1999) documented that dandelion growth responded positively to $\mathrm{K}$ fertilization and increased 17- to 20 -fold vs. nonfertilized controls in a mesotrophic grassland.

The timing of fertilizer applications is crucial to increase the ability of turfgrasses to outcompete weeds. For example, Kentucky bluegrass fertilized in spring and fall had significantly lower crabgrass densities than when fertilized in fall or summer (Dunn et al., 1981). Tall fescue fertilized in fall with two split applications each of $73 \mathrm{~kg} \mathrm{~N} \mathrm{ha}^{-1}$ was more competitive against weeds than a single spring application of $73 \mathrm{~kg} \mathrm{~N} \mathrm{ha}^{-1}$ (Hall, 1980). Fertilizer aids turfgrass growth and competitiveness but neither fall nor spring fertilization had an effect on crabgrass germination levels (Turner \& van Acker, 2014).

Placement of fertilizer may also be important in weed suppression. The application of fertilizer close to the roots has been shown to suppress weed growth in agronomic studies (Chauhan \& Ahugho, 2013; Kirkland \& Beckie, 1998; Mashingaidze et al., 2010). This weed suppressing effect of fertilizer placement has not been observed in landscape planting systems because of the ample availability of nutrients in the soil (Marble et al., 2015) but might have implications for turfgrass areas that are constructed on sand-based soil.

\section{6 | BIOHERBICIDES}

\section{1 | Fungi based herbicides}

Phoma herbarum is a fungal plant pathogen that causes leaf spot on a wide range of host plants (Gilardi, Matic, Gullino, \& Garibaldi, 2017). The fungus produces the toxic metabolite 3-nitro-1,2-benzenedicarboxylic acid (3nitrophthalic acid), which has herbicidal activity (Vikrant, Verma, Rajak, \& Pandey, 2006). The efficacy of P. herbarum was tested on dandelion transplanted into an existing Kentucky bluegrass sward (Neumann \& Boland, 1999). Significantly higher rates of dandelion foliage infection were observed in plants inoculated with $P$. herbarum strains formulated with potato dextrose broth together with either 5\% durum semolina, $1 \%$ guar gum, or 5\% gluten flour vs. a potato dextrose broth control $3 \mathrm{wk}$ 
postinoculation. Field conditions reduce the efficacy of $P$. herbarum to infect dandelion (Schnick \& Boland, 2004). The authors observed that in the spring trial, foliage infection rates were lower because dandelion was able to outgrow the disease. Therefore, it is unclear if $P$. herbarum is capable of imposing a long-term fitness cost on dandelion.

Phoma macrostoma was isolated from Canada thistle [Cirsium arvense (L.) Scop.] and caused chlorosis and bleaching of young leaves in broadleaf weeds by producing phytotoxic macrocidins (Graupner et al., 2003, 2006). Differences in efficacy of $P$. macrostoma on broadleaf weeds were reported by Smith et al. $(2013,2015)$ with dandelion being most effectively controlled. Weeds have a very low risk of developing resistance to macrocidins isolated from P. macrostoma because of their diverse modes of action (Hubbard, Taylor, Bailey, \& Hynes, 2016). According to Boerema, de Gruyter, Noordeloos, and Hamers (2004), P. macrostoma is a weak and opportunistic pathogen, which enters host plants through wounds. Phoma macrostoma 94-44B was granted full registration in Canada to be sold and used for the control of a broad spectrum of broadleaf weeds found in turfgrass (Hynes, 2018). Mycelial fragments of P. macrostoma applied to soil caused photobleaching and death to dandelion but had no effect on monocotyledonous weeds (Bailey \& Derby, 2001). For broadleaf weed control in turfgrass the $P$. macrostoma isolate $94-44 \mathrm{~B}$ was formulated into a granule for soil applications to act as a pre- and postemergence biological herbicide (Bailey, Pitt, Leggett, Sheedy, \& Derby, 2011). Field trials conducted at three locations (silt-loam, $\mathrm{pH}$ 7.1; sandy loam, $\mathrm{pH}$ 7.8; and silt loam pH 7) in Canada, with high dandelion densities reported an average reductions of dandelion ranging from $70-90 \%$ in summer and late fall. Product efficiency was further increased by $10-20 \%$ when $\mathrm{N}$ treatments were added (Bailey, Falk, Derby, Melzer, \& Boland, 2013). Year-to-year efficiency of $P$. macrostoma was influenced by environmental conditions, soil type, and organic matter content. Negative interactions between $P$. macrostoma and sulfate applications were observed, which reduced efficiency of dandelion control (Bailey et al., 2013). Currently no data are available on the efficiency of $P$. macrostoma to control other common turfgrass weeds.

Sclerotinia minor is the causal agent of lettuce drop (Wymore \& Lorbeer, 1987). The fungus produces sclerotia that survives in the soil. Sclerotinia minor can infest a wide range of host plants including common turfgrass weeds such as dandelion, white clover, and broadleaf plantain (Plantago major L.) (Harding \& Raizada, 2015). The isolate IMI344141 was identified as suitable candidate for the production of bioherbicides (Briere, Watson, \& Hallett, 2000). During pathogenesis oxalic acid accumulates in the host plant and synergistically enhances the effect of pectolytic enzymes (Marciano, Di Lenna, \& Magro, 1983).
Mycelia of $S$. minor require a susceptible host to persist in the environment, otherwise they decay after $10 \mathrm{~d}$ when applied to turfgrass areas (Watson, 2007). A Kentucky bluegrass sward treated with an inoculum of a $S$. minor strain six times during the first year and four times during the following year resulted in a reduction of $80.7 \%$ of dandelion (Riddle, Burpee, \& Boland, 1991). A subsequent 3-yr field study showed that $S$. minor was as effective at controlling white clover, broadleaved plantain, birdsfoot trefoil, and common ragweed (Ambrosia artemisiifolia L.) as the herbicide Killex (active ingredients: 2,4 D; mecoprop and dicamba) (Abu-Dieyeh \& Waston, 2007).

\section{2 | Bacterial based herbicides}

Propagation of bacteria is less dependent on environmental influences than to fungi (Li et al., 2003) and is therefore more rapid and more suitable for potential genetic modifications (Harding \& Raizada, 2015; Johnson, Wyse, \& Jones, 1996; Li et al., 2003). Several bacterial strains of $P$. fluorescens were identified as agents to control annual bluegrass and certain graminaceous plants (Banowetz, Azevedo, Armstrong, \& Mills, 2009; Kennedy, 2016). Soilapplied bacteria, such as P. fluorescens strain D7, produce a complex of a lipopolysaccharide and extracellular peptides, which inhibit root and shoot growth of annual bluegrass but no other turfgrass species (Gurusiddaiah, Gealy, Kennedy, \& Ogg, 1994; Kennedy, 2016). Furthermore, the $P$. fluorescens strain WH6 produces oxyvinylglycines and therefore inhibits germination of a broad range of plants (Banowetz et al., 2009). Fall applications of the bacterium led to establishment in the soil and propagation during cool temperatures similar to annual bluegrass root growth. Therefore, $P$. fluorescens has potential to be developed into a selective postemergence soil spray to reduce the annual bluegrass seed bank in turfgrass swards (Kennedy, 2016). Johnston and Golob (2017) found that $P$. fluorescens applications to an annual bluegrass and Kentucky bluegrass golf fairway made in fall 2015 and spring 2016 were ineffective at controlling annual bluegrass. Currently $P$. fluorescens strain D7 is registered for the control of agricultural weeds but not annual bluegrass (USEPA, 2014).

Strains of the Gram-negative bacterium Xanthomonas campestris cause bacterial wilt on susceptible plants (Imaizumi, Nishino, Miyabe, Fujimori, \& Yamada, 1997). Bacteria of $X$. campestris enter host plants through natural openings such as stomata or wounds and multiply in intercellular spaces or the xylem. Pathogenicity is caused by the injection of effector proteins or the manipulation of the plant transcriptome by mimicking 
transcriptional activators (Kay \& Bonas, 2009). In Japan, $X$. campestris pv. poannua was formulated into a commercially available product (Nishino \& Tateno, 2000). The bacterium is host specific for annual bluegrass and does not affect other turfgrasses (Fujimori, 1999; Zhou \& Neal, 1995). In field tests, annual bluegrass abundance was reduced by $40 \%$ when $X$. campestris pv. poannua formulated as a spray was repeatedly applied (Zhou \& Neal, 1995). However, 2-5 wk after discontinuing applications recovery occurred. Johnson et al. (1996) found that infection of annual bluegrass in bermudagrass golf greens only occurred when $X$. campestris pv. poannua was applied with a surfactant and during mowing. Six monthly applications resulted in $70 \%$ control of annual bluegrass (Johnson et al., 1996).

\section{3 | Organic products with herbicidal mechanisms}

Corn gluten meal derived from maize (Zea mays L.) produces allelopathic chemicals such as benzoxazinoids, which inhibit root growth, enzyme activity, and germination of annual grassy weeds and agricultural weed plant species such as okra [Abelmoschus esculentus (L.) Moench] (Ayeni \& Kayode, 2013; Christians, 1991; Jabran \& Farooq, 2013). Other herbicidal activity is likely to be caused by multiple dipeptides, which have an inhibitory effect on weed seed germination (Baker \& Grant, 2018; Unruh, Christians, \& Horner, 1997).

In greenhouse studies, corn gluten meal showed effective herbicidal activity on black medic (Medicago lupulina L.), buckhorn plantain (Plantago lanceolata L.), dandelion, crabgrass, and other common turfgrass weeds (Baker \& Grant, 2018). However, other studies question the claims of herbicidal activity and suggest that the $\mathrm{N}$ concentrations in corn gluten meal simply give turfgrasses a competitive advantage over weeds that allows them to reduce dandelion, crabgrass, and clover densities (Christians \& Dant, 2005; John \& DeMuro, 2013; Patton \& Weisberger, 2012). In another study, liquid corn gluten meal showed no herbicidal effect on weeds in turfgrass trials (Lyons, Jordan, \& Carey, 2015). The conclusion that can be drawn from these studies is that corn gluten meal can be used as an organic $\mathrm{N}$ source but not as an herbicidal alternative to control weeds in turfgrass settings.

Acetic acid is produced by aerobic bacteria, during the fermentation of ethanol containing plant material (Webber, Harris, Sherefler, Durnova, \& Christopher, 2005). Acetic acid applied to turfgrass causes the nonselective breakdown of foliage (Webber \& Shrefler, 2006). In the United States, acetic acid products with $<8 \%$ concentration do not have to be registered and are effective in con- trolling young weeds with one to two leaves (Webber \& Shrefler, 2006). Improved control can be achieved by using higher rates of $20 \%$ acetic acid and increasing application volumes (Webber \& Shrefler, 2006). The effectiveness of acetic acid in controlling weeds is also dependent on maximizing the area of contact with the foliage, which will be determined by the growth habit of the weed and the method of product application (Evans, Bellinder, \& Goffinet, 2009).

\section{7 | THERMAL WEED CONTROL}

Thermal weed control can be used to sterilize a seedbank or spot spray or burn existing weeds. Hoyle, McElroy, and Rose (2012) documented good broadleaf and grassy weed but less yellow nutsedge (Cyperus esculentus L.) control before tall fescue establishment when using an enclosed flaming system. The authors reported that $6 \mathrm{wk}$ after seeding, tall fescue reached $>60 \%$ establishment when flaming was applied in fall vs. summer. In agriculture, steaming soil with $70-100{ }^{\circ} \mathrm{C}$ water steam to a depth of $10 \mathrm{~cm}$ for 3-8 min is used to kill weed seeds in soil (Bond, Turner, \& Grundy, 2003). During such a sterilization process, microorganism abundance is reduced for at least 2 mo and the community function might change after recovery (Roux-Michollet et al., 2008). Steaming soil could be an alternative to pre-emergence herbicides to treat newly constructed turfgrass areas. For spot treatments, hot water was successfully used to reduce common broadleaf dock (Rumex obtusifolius L.) by $80 \%$ without causing damage to the soil structure (Latsch, Anken, Herzog, \& Sauter, 2017). Large patches of weeds can also be treated with solarization. Solarization requires covering patches of weed with plastic covers during favorable conditions. After some time, heat and solar radiation injures weeds but also dries out the seedbank (Horowitz, Regev, \& Herzlinger, 1983). However, this method might only be appropriate for small turfgrass areas because installing covers is labor intensive and covers need to be in place for several days. Other thermal weed control methods include freezing, electric currents, irradiation, microwave radiation, and ultraviolet light.

Targeted mechanical or thermal weed control in large turfgrass areas would require high-resolution field scouting systems to initially detect weeds (Bell, Kurse, \& Krum, 2013). In a next step, automated systems could be developed to remove the weed. Weeds can be removed by laser treatment (Mathiassen, Bak, Christensen, \& Kudsk, 2006) or hot water $\left(95^{\circ} \mathrm{C}\right)$, which was more effective to spot treat weeds than flaming, steam, hot air, and steel brushing (Kristoffersen, Rask, \& Larsen, 2008). 


\section{8 | PERSPECTIVE ON NONCHEMICAL WEED CONTROL}

A complete ban of herbicides will most likely require a change in perception of weeds and playing quality expectations. In cases where herbicides are banned, weeds may have to be treated only if they interfere with playing quality. In such occasions, threshold levels need to be established to determine which types of weeds need to be treated, in which playing areas, and at what infestation level (e.g. percentage of playing area covered by weeds). Treating weeds solely for aesthetic reasons will most likely no longer be an acceptable justification for legislators. If users of turfgrass areas still object to the presence of weeds for mainly aesthetic reasons, a stronger effort needs to be placed on convincing legislators as to why weeds interfere with the purpose of the area and why they need to be removed.

Future research should focus on assessing the competitiveness of certain turfgrass species and cultivars against weeds under different maintenance regimes and within the limitations of producing turfgrass areas of acceptable playing quality. The literature suggests that broadleaf weeds are reduced when more $\mathrm{N}$ is applied; therefore, finding a balance between what is needed and what is environmentally safe and sustainable is critical. In the context of achieving sustainability, increased attention has been placed on fertilization needed by turfgrass areas. The prevailing opinion of the public in general and legislators in particular has been that turfgrass in general and golf courses in particular are overfertilized (May, Hall, Chalmers, \& Carry, 2009), and for this reason, minimum levels for sustainable nutrition could be used as guidelines (Woods, Stowell, \& Gelernter, 2014). These guidelines were developed and published from a data set of over 16,000 soil samples that were collected on turfgrass that was of acceptable quality (PACE Turf, 2014). However, since most of these soil samples were collected in the United States, it might be fair to assume that herbicides were applied as part of the maintenance. Consequently, caution needs to be used when minimum levels for sustainable nutrition standards are applied but herbicides are not available for weed control.

In the future, the best approach for turfgrass managers might be to use remote sensing technology to detect deficiencies such as poor irrigation uniformity, soil compaction, and nutrient deficiencies. Improving overall plant health will encourage dense growth of turfgrasses and increases the competitive ability of turfgrasses to suppress weeds. Precision turfgrass management might be a useful tool to address these issues. Unmanned aerial vehicles or autonomous ground-based sensing vehicles equipped with cameras, multispectral sensors, remote sensors, or other equipment can be used to collect data about turfgrass health such as monitoring water stress, nutrient deficiencies, pest pressure, and salinity (Carrow, Krum, Flitcroft, \& Cline, 2010; Caturegli et al., 2016; Krum, Carrow, \& Karnok, 2010; Stowell \& Gelernter, 2006). Spectral reflectance can provide information about leaf-area index, chlorophyll content, biomass, drought stress, and nutritional status (Agati et al., 2013; Caturegli et al., 2015; Finke, 1992; Foschi, Volterrani, Grossi, \& Miele, 2009). Satellite remote sensing can also be used to assess $\mathrm{N}$ status of turfgrasses spatially and in real time (Caturegli et al., 2015). In the future, normalized difference vegetation index sensors would ideally be mounted to mowing units to collect data in near real time. These technologies may be able to detect deficiencies and poor quality or sparse turfgrass but are unable to pinpoint the cause of the inadequacies. For example, to determine optimal (or minimal) fertilizer requirements, soil sampling or leaf tissue analysis is still needed. Moreover, precision fertilization practices include zoning a golf course into site-specific management units, where areas with similar usages, soil compositions, topography, plant responses, and microclimates are zoned (Krum et al., 2010). A composite soil sample could be taken from each zoned area to analyze soil nutrient status, which requires less sampling than grid sampling (Carrow et al., 2010; Ikenaga \& Inamura, 2008; Johnson et al., 2001; Shaner, Khosla, Brodahl, Buchleiter, \& Farahani, 2008). A sensible approach might be to use soil sampling site-specific management units to measure the soil pool of rather immobile nutrients, such as $\mathrm{P}$ and K (Giehl \& Wirén, 2014), and to use remote sensing techniques on a more frequent basis to measure mobile nutrient status such as $\mathrm{N}$.

The most effective method of removing existing weeds in turfgrass swards without the use of synthetic herbicides might be to spot spray with hot water or high concentrations of nonselective biological products such as acetic acid. Host-specific biological products based on fungi or bacteria are only available in selective countries around the world, and their efficiency is questionable. Much effort is ongoing to increase the efficacy of these products and they might become viable options to synthetic herbicides in the future. Thorough testing, including controlled screenings and field trials, are needed to provide information about the host-specific persistence of biological products in changing environments over time. The development of robotic machines to detect and remove weeds might be one of the more promising approaches to control weeds in the future. Detecting and removing weeds in dense turfgrass swards is challenging but currently under development.

Sustainable turfgrass management will become increasingly important for budgetary and environmental reasons; however, approaches that address both objectives (cutting 
cost and environmental protection) are not always possible as they can be mutually exclusive. Therefore, if synthetic herbicides (or pesticides in general, for that matter) are being banned from use on turfgrass areas, future research is needed to develop maintenance strategies that include minimum levels for sustainable nutrition guidelines that focus on outcompeting weeds and on the prevention of turfgrass pests in general.

\section{ACKNOWLEDGMENTS}

Financial support of this report was provided by the Turfgrass University Research Foundation (TuRF), Nederlandse Golf Federatie (NGF), Nederlandse Vereniging van Golfaccommodaties (NVG), and Nederlandse Greenkeepers Associatie (NGA). The authors are also grateful for the constructive and insightful comments provided by the anonymous reviewers; they greatly improved the manuscript.

\section{ORCID}

Daniel Hahn (Di) https://orcid.org/0000-0002-7513-747X Rossana Sallenave (i) https://orcid.org/0000-0003-24209282

\section{Bernd Leinauer (10 https://orcid.org/0000-0002-3700-2005}

\section{REFEREN CES}

Aamlid, T. S. (1992). Dormancy and germination of temperate grass seed as affected by environmental conditions - A literature review. Norwegian Journal of Agricultural Sciences, 6, 217-240.

Abu-Dieyeh, M. H., \& Watson, A. K. (2007). Population dynamics of broadleaf weeds in turfgrass as influenced by chemical and biological control methods. Weed Science, 55, 371-380. https://doi.org/10. 1614/WS-06-144

Adams, W. A. (1980). Effects of nitrogen fertilization and cutting height on the shoot growth, nutrient removal, and turfgrass composition of an initially perennial ryegrass dominant sports turf. In J. B. Beard (Ed.), Proceedings of the Third International Turfgrass Research Conference, Munich, West Germany, 11-13 July 1977 (pp. 343-350). Madison, WI: ASA, CSSA, SSSA, and International Turfgrass Society. https://doi.org/10.2135/1974. proc3rdintlturfgrass.c40

Agati, G., Foschi, L., Grossi, N., Guglielminetti, L., Cerovic, Z. G., \& Volterrani, M. (2013). Fluorescence-based versus reflectance proximal sensing of nitrogen content in Paspalum vaginatum and Zoysia matrella turfgrasses. European Journal of Agronomy, 45, 39 51. https://doi.org/10.1016/j.eja.2012.10.011

Akbari, M., Sajedi, N., Gomarian, M., \& Akbari, M. (2015). Allelopathic effects of cool-season turfgrass mixture clipping extract on four weed species and detection of the phenolic compounds. International Journal of Horticultural Science and Technology, 2, 141149.

Ayeni, M. J., \& Kayode, J. (2013). Allelopathic effects of sorghum stem and maize inflorescence residues on the germination and growth of okra (Abelmoschus esculentus L.). Journal of Food, Agriculture \& Environment, 11, 320-323.
Bailey, K. L., \& Derby, J. (2001). Fungal isolates and biological control compositions for the control of weeds. U.S. Patent 60/294475.

Bailey, K. L., Falk, S., Derby, J. A., Melzer, M., \& Boland, G. J. (2013). The effect of fertilizers on the efficacy of the bioherbicide, Phoma macrostoma, to control dandelions in turfgrass. Biological Control, 65, 147-151. https://doi.org/10.1016/j.biocontrol.2013. 01.003

Bailey, K. L., Pitt, W. M., Leggett, F., Sheedy, C., \& Derby, J. (2011). Determining the infection process of Phoma macrostoma that leads to bioherbicidal activity on broadleaved weeds. Biological Control, 59, 268-276. https://doi.org/10.1016/j.biocontrol.2011.06. 019

Baker, B. P., \& Grant, J. A. (2018). Corn gluten meal profile. Retrieved from https://ecommons.cornell.edu/bitstream/handle/ 1813/56121/corn-gluten-meal-MRP-NYSIPM.pdf?sequence= $1 \&$ isAllowed $=\mathrm{y}$

Banowetz, G. M., Azevedo, M. D., Armstrong, D. J., \& Mills, D. I. (2009). Germination arrest factor (GAF): Part 2. Physical and chemical properties of a novel, naturally occurring herbicide produced by Pseudomonas fluorescens strain WH6. Biological Control, 50, 103-110. https://doi.org/10.1016/j.biocontrol.2009.03.011

Barkley, D. G., Blaser, R. E., \& Schmidt, R. E. (1965). Effect of mulches on microclimate and turf establishment. Agronomy Journal, 57, 189-192. https://doi.org/10.2134/agronj1965. 00021962005700020016x

Barton, L., \& Colmer, T. D. (2006). Irrigation and fertiliser strategies for minimising nitrogen leaching from turfgrass. Agricultural Water Management, 80(1), 160-175. https://doi.org/10.1016/j. agwat.2005.07.011

Barzman, M., \& Dachbrodt-Saaydeh, S. (2011). Comparative analysis of pesticide action plans in five European countries. Pest Management Science, 67, 1481-1485. https://doi.org/10.1002/ps.2283

Beard, J. B., Martin, D. P., \& Mercer, F. B. (1980). Investigation of net-sod production as a new technique. In J. B. Beard (Ed.), Proceedings of the Third International Turfgrass Research Conference, Munich, West Germany, 11-13 July 1977 (pp. 353-360). Madison, WI: ASA, CSSA, SSSA, and International Turfgrass Society. https: //doi.org/10.2135/1974.proc3rdintlturfgrass.c41

Begon, M., Harper, J. L., \& Townshend, G. R. (1996). Ecology. Individuals, populations and communities. Oxford, UK: Blackwell Scientific Publications

Bell, G. E., Kruse, J. K., \& Krum, J. M. (2013). The evolution of spectral sensing and advances in precision turfgrass management. Turfgrass: Biology, Use, and Management, 56, 1151-1188. https://doi.org/ 10.2134/agronmonogr56.c30

Bell, G. E., Odorizzi, E., \& Danneberger, T. K. (1999). Reducing populations of annual bluegrass and roughstalk bluegrass in bentgrass fairways: A nutritional approach. Weed Technology, 13, 829-834. https://doi.org/10.1017/S0890037X00042305

Bertin, C., Senesac, A. F., Rossi, F. S., DiTommaso, A., \& Weston, L. A. (2009). Evaluation of selected fine-leaf fescue cultivars for their turfgrass quality and weed suppressive ability in field settings. HortTechnology, 19, 660-668. https://doi.org/10.21273/HORTSCI. 19.3.660

Bertin, C., Yang, X., \& Weston, L. A. (2003). The role of root exudates and allelochemicals in the rhizosphere. Plant and Soil, 256, 67-83. https://doi.org/10.1023/A:1026290508166

Boerema, G. H., de Gruyter, J., Noordeloos, M. E., \& Hamers, M. E.C. (2004). Phoma identification manual: Differentiation of 
specific and infra-specific taxa in culture. Cambridge, MA: CABI Publishing.

Bond, W., Turner, R. J., \& Grundy, A. C. (2003). A review of non-chemical weed management. Retrieved from https:// gardenorganic.org.uk/sites/www.gardenorganic.org.uk/files/ updated_review_0.pdf

Bowman, W. D., Theodose, T. A., Schardt, J. C., \& Conant, R. T. (1993). Constraints of nutrient availability on primary production in two alpine tundra communities. Ecology, 74, 2085-2097. https: //doi.org/10.2307/1940854

Brede, A. D., \& Duich, J. M. (1984). Establishment characteristics of Kentucky bluegrass-perennial ryegrass turf mixtures as by seeding rate and ratio. Agronomy Journal, 76, 875-879. https://doi.org/10. 2134/agronj1984.00021962007600060004x

Bridges, D. C. (1994). Impact of weeds on human endeavors. Weed Technology, 8, 392-395. https://doi.org/10.1017/S089 0037 X00038987

Briere, S. C., Watson, A. K., \& Hallett, S. G. (2000). Oxalic acid production and mycelial biomass yield of Sclerotinia minor for the formulation enhancement of a granular turf bioherbicide. Biocontrol Science and Technology, 10, 281-289. https://doi.org/10.1080/ 09583150050044556

British Society of Plant Breeders. (2020). Turfgrass 2020. Retrieved from http://www.plantbreedingmatters.com/sg_userfiles/BSPB_ Turfgrass_2020_LRes.pdf

Brodie, B. B., \& Burton, G. W. (1967). Nematode population reduction and growth response of Bermuda turf as influenced by organic pesticide applications. Plant Disease Report, 51, 562-566.

Busey, P. (2003). Cultural management of weeds in turfgrass. Crop Science, 43, 1899-1911. https://doi.org/10.2135/cropsci2003. 1899

Busey, P., Broschat, T. K., \& Center, B. J. (1982). Classification of St. Augustinegrass. Crop Science, 22, 469-473. https://doi.org/10.2135/ cropsci1982.0011183X002200030008x

Calhoun, R. N., Rinehart, G. J., Hathaway, A. D., \& Buhler, D. D. (2005). Maximizing cultural practices to minimize weed pressure and extend herbicide treatment interval in a cool-season turfgrass mixture. International Turfgrass Society Research Journal, 10, 11841188.

Calvache, S., T., Espevig, T.E., Andersen, J., E., Joner, A. Kvalbein, Pettersen, T., \& Aamlid, T. S. (2017). Nitrogen, phosphorus, mowing height, and arbuscular mycorrhiza effects on red fescue and mixed fescue-bentgrass putting greens. Crop Science, 57, 537-549. https://doi.org/10.2135/cropsci2016.04.0240

Carrow, R. N., Krum, J. M., Flitcroft, I., \& Cline, V. (2010). Precision turfgrass management: Challenges and field applications for mapping turfgrass soil and stress. Precision Agriculture, 11, 115-134. https://doi.org/10.1007/s11119-009-9136-y

Caturegli, L., Casucci, M., Lulli, F., Grossin, N., Gaetani, M., Magni, S., ... Volterrani, M. (2015). GeoEye-1 satellite versus ground-based multispectral data for estimating nitrogen status of turfgrasses. International Journal of Remote Sensing, 36, 2238-2251. https://doi. org/10.1080/01431161.2015.1035409

Caturegli, L., Corniglia, M., Gaetani, M., Grossi, N., Magni, S., Migliazzi, M. ... Raffaelli, M. (2016). Unmanned aerial vehicle to estimate nitrogen status of turfgrasses. PLoS ONE, 11, 1-13. https: //doi.org/10.1371/journal.pone.0158268

Chauhan, B. S., \& Ahugho, S. B. (2013). Fertilizer placement affects weed growth and grain yield in dry-seeded rice (Oryza sativa L.) systems. American Journal of Plant Sciences, 4, 1260-1264. https: //doi.org/10.4236/ajps.2013.46155

Christians, N. E., \& Dant, L. (2005). Corn gluten meal/urea crabgrass control study - Year 6. Retrieved from http://www.d.lib.msu.edu/ iowat/

Christians, N. E. (1991). Preemergence weed control using corn gluten meal. US Patent 5,030,268.

Christians, N. E., Patton, A. J., \& Law, Q. D. (2016). Fundamentals of turfgrass management (5th ed.). Hoboken, NJ: John Wiley \& Sons.

Cisar, J. L. (2004). Managing turf sustainably. New directions for a diverse planet. In Proceedings of the 4th International Crop Science Congress, 26 Sept.-1 Oct. 2004 [CD-ROM]. Brisbane, Australia: Crop Science Congress.

Cropper, K., Munshaw, G., \& Barrett, M. (2017). Optimum seasonal mowing heights for smooth crabgrass reduction in tall fescue lawns. HortTechnology, 27, 73-77. https://doi.org/10.21273/ HORTTECH03588-16

Dahl-Jensen, A. M., Bühler, O., Kvalbein, A., \& Aamlid, T. (2017). Evaluation of the occurrence of turfgrasses and weeds after repeated overseeding on fairways. International Turfgrass Society Research Journal, 13, 389-393.

Dahl-Jensen, A. M., Norman Petersen, K., \& Aamlid, T. (2014). Pesticide-free management of weed on golf courses: Current situation and future challenges. European Journal of Turfgrass Science, 42, 61-64.

Davis, R. R. (1958). The effect of other species and mowing height on persistence of lawn grasses. Agronomy Journal, 50, 671-673. https: //doi.org/10.2134/agronj1958.00021962005000110009x

DeBels, B. T., Griffith, S.E., Kreuser, W.C., Melby, E.S., \& Soldat, D. J. (2012). Evaluation of mowing height and fertilizer application rate on quality and weed abundance of five home lawn grasses. Weed Technology, 26, 826-831. https://doi.org/10.1614/WT-D-1200062.1

Department for Environment, Food and Rural Affairs. (2015). Amenity pesticides in the United Kingdom. Retrieved from https://www.gov.uk/government/statistics/pesticide-usage-sur vey-amenity-pesticides-in-the-uk-2016

De Prado, R. A., \& Franco, A. R. (2004). Cross-resistance and herbicide metabolism in grass weeds in Europe: Biochemical and physiological aspects. Weed Science, 52, 441-447. https://doi.org/ 10.1614/P2002-168A

Dernoeden, P. H., Carroll, M. J., \& Krouse, J. M. (1993). Weed management and tall fescue quality as influenced by mowing, nitrogen, and herbicides. Crop Science, 33, 1055-1061. https://doi.org/ 10.2135/cropsci1993.0011183X003300050036x

Dernoeden, P. H., Carroll, M. J., \& Krouse, J. M. (1994). Mowing of three fescue species for low-maintenance turf sites. Crop Science, 34, 1645-1649. https://doi.org/10.2135/cropsci1994. 0011183X003400060041x

Dernoeden, P. H., Fidanza, M. A., \& Krouse, J. M. (1998). Low maintenance performance of five Festuca species in monostands and mixtures. Crop Science, 38, 434-439. https://doi.org/10.2135/ cropsci1998.0011183X003800020027x

Dest, W. M., \& Guillard, K. (1987). Nitrogen and phosphorus nutritional influence on bentgrass-annual bluegrass community composition. Journal of the American Society for Horticultural Science, 112, 769-773.

Devienne-Barret, F., Justes, E., Machet, J. M., \& Mary, B. (2000). Integrated control of nitrate uptake by crop growth rate and soil nitrate 
availability under field conditions. Annals of Botany, 86, 995-1005. https://doi.org/10.1006/anbo.2000.1264

DiTommaso, A., \& Aarssen, L. W. (1989). Resource manipulations in natural vegetation: A review. Vegetatio, 84, 9-29. https://doi.org/ 10.1007/BF00054662

Dodd, M. E., Silvertown, J., McConway, K., Potts, J., \& Crawley, M. (1994). Application of the British national vegetation classification to the communities of the park grass experiment through time. Folia Geobotanica et Phytotaxonomica, 29, 321-334. https: //doi.org/10.1007/BF02882911

Dunn, J. H., Nelson, C. J., \& Winfrey, R. D. (1981). Effects of mowing and fertilization on quality of ten Kentucky bluegrass cultivars. In R. W. Sheard (Ed.), Proceedings of the 4th International Turfgrass Research Conference, Guelph, ON, Canada. 19-23 July 1981 (pp. 293-301). Guelph, ON, Canada: Ontario Agricultural College, University of Guelph \& International Turfgrass Society.

Elford, E. M., Tardif, F. J., Robinson, D. E., \& Lyons, E. M. (2008). Effect of perennial ryegrass overseeding on weed suppression and sward composition. Weed Technology, 22, 231-239. https://doi.org/ 10.1614/WT-07-120.1

Escrit, J. R., \& Lidgate, H. J. (1964). Report on fertilizer trials. Journal of the Sports Turf Research Institute, 40, 7-42.

European Commission. (2017). EU pesticides database. Retrieved from https://ec.europa.eu/food/plant/pesticides/eu-pesticides-da tabase/public/?event=homepage\&language $=\mathrm{EN}$

Evans, G. J., Bellinder, R.R., \& Goffinet, M. C. (2009). Herbicidal effects of vinegar and a clove oil product on redroot pigweed (Amaranthus retroflexus) and velvetleaf (Abutilon theophrasti). Weed Technology, 23, 292-299. https://doi.org/10.1614/WT-08-158.1

Fales, S. L., \& Wakefield, R. C. (1981). Effects of turfgrass on the establishment of woody plants. Agronomy Journal, 73, 605-610. https://doi.org/10.2134/agronj1981.00021962007300040009x

Finke, P. A. (1992). Integration of remote sensing data in the simulation of spatially variable yield of potatoes. Soil Technology, 5, 257270. https://doi.org/10.1016/0933-3630(92)90026-W

Foschi, L., Volterrani, M., Grossi, N., \& Miele, S. (2009). Monitoring relative water content in turf with canopy spectral reflectance. International Turfgrass Society Research Journal, 11, 765-778.

Fujimori, T. (1999). New developments in plant pathology in Japan. Australasian Plant Pathology, 28, 292-297. https://doi.org/10.1071/ AP99046

Gastal, F., \& Lemaire, G. (2002). N uptake and distribution in crops: An agronomical and ecophysiological perspective. Journal of Experimental Botany, 53, 789-799. https://doi.org/10.1093/ jexbot/53.370.789

Gaussoin, R. E., \& Branham, B. E. (1989). Influence of cultural factors on species dominance in a mixed stand of annual bluegrass/creeping bentgrass. Crop Science, 29, 480-484. https://doi. org/10.2135/cropsci1989.0011183X002900020048x

German Golf Association (2017). List of permitted plant protection products for golf courses. (In German). Retrieved from http:// www.golf.de

Gibeault, V. A., Meyer, J. L., \& Youngner, V. B. (1985). Irrigation of turfgrass below replacement of evapotranspiration as a means of water conservation: Weed invasion in three cool season turfgrasses. In F. Lemaire (Ed.), Proceedings of the 5th International Turfgrass Research Conference, Avignon, France. 15 July 1985 (pp. 365-372). Paris: Institut national de la recherche agronomique.
Giehl, R. F., \& von Wirén, N. (2014). Root nutrient foraging. Plant Physiology, 166, 509-517. https://doi.org/10.1104/pp.114.245225

Gilardi, G., Matic, S., Gullino, M. L., \& Garibaldi, A. (2017). First report of Phoma herbarum causing leaf spot of woodland sage (Salvia nemorosa) in Northern Italy. Plant Disease, 101, 1824. https: //doi.org/10.1094/PDIS-04-17-0606-PDN

Golf Course Superintendents Association of America. (2017). Golf course environmental profile - Pest management practices on U.S. golf courses. Retrieved from https://www.gcsaa. org/docs/default-source/Environment/phase-2-pest-survey-fullreport.pdf?sfvrsn=1da4173e_0

Goss, R. L. (1974). Effects of variable rates of sulfur on the quality of putting green bentgrass. In E. C. Roberts (Ed.), Proceedings of the 2nd International Turfgrass Research Conference, Blacksburg, VA. 19-21 June 1973 (pp. 172-175). Madison, WI: ASA and CSSA.

Goss, R. L., Brauen, S. E., \& Orton, S. P. (1975). The effects of N, P, K and $\mathrm{S}$ on Poa annua L. in bentgrass putting green turf. Journal of the Sports Turf Research Institute, 51, 74-82.

Gough, L., Osenberg, C. W., Gross, K. L., \& Collins, S. L. (2000). Fertilization effects on species density and primary productivity in several herbaceous plant communities. Oikos, 89, 428-439. https: //doi.org/10.1034/j.1600-0706.2000.890302.x

Government of the Netherlands. (2017). Green deal. Retrieved from https://www.greendeals.nl/english

Gray, E., \& Call, N. M. (1993). Fertilization and mowing on persistence of Indian mockstrawberry (Duchesnea indica) and common blue violet (Viola papilionacea) in a tall fescue (Festuca arundinacea) lawn. Weed Science, 41, 548-550. https://doi.org/10.1017/ S0043174500076293

Grime, J. P. (1973). Competitive exclusion in herbaceous vegetation. Nature, 242, 344-347. https://doi.org/10.1038/242344a0

Graupner, P. R., Carr, A., Clancy, E., Gilbert, J., Bailey, K. L., Derby, J. A., \& Gerwick, B. C. (2003). The macrocidins: Novel cyclic tetramic acids with herbicidal activity produced by Phoma macrostoma. Journal of Natural Products, 66, 1558-1561. https://doi.org/ 10.1021/np030193e

Graupner, B., Gerwick, C., Sidall, T. L., Carr, A. W. Clancey, E., Gilbert, J. R., ... Derby, J. (2006). Chlorosis inducing phytotoxic metabolites: New herbicides from Phoma macrostoma. Natural Products for Pest Management, 3, 37-47. https://doi.org/10.1021/ bk-2006-0927.ch003

Gurusiddaiah, S., Gealy, D. R., Kennedy, A. C., \& Ogg, A. G. (1994). Isolation and characterization of metabolites from Pseudomonas fluorescens-D7 for control of downy brome (Bromus tectorum). Weed Science, 42, 492-501. https://doi.org/10.1017/ S0043174500076827

Haley, J. E., Wehner, D. J., Fermanian, T. W., \& Turgeon, A. J. (1985). Comparison of conventional and mulching mowers for Kentucky bluegrass maintenance. Horticultural Science, 20, 105-107.

Hall, J. R. (1980). Effect of cultural factors on tall fescue-Kentucky bluegrass sod quality and botanical composition. In J. B. Beard (Ed.), Proceedings of the Third International Turfgrass Research Conference, Munich, West Germany, 11-13 July 1977 (pp. 367-377). Madison, WI: ASA, CSSA, SSSA, and International Turfgrass Society.

Hansford, W. B. (1981). Sprayable hydromulch. U.S. Patent 4,297,810.

Harding, D. P., \& Raizada, M. N. (2015). Controlling weeds with fungi, bacteria and viruses: A review. Frontiers in Plant Science, 6, 1-14. https://doi.org/10.3389/fpls.2015.00659 
Harris, M. (2008). More effective overseeding. Greenkeeper International, May, 33-35.

Haugland, E., \& Froud-Williams, R. J. (1999). Improving grasslands: The influence of soil moisture and nitrogen fertilization on the establishment of seedlings. Journal of Applied Ecology, 36, 263270. https://doi.org/10.1046/j.1365-2664.1999.00397.x

Hazard, L., \& Ghesquiere, M. (1995). Evidence from the use of isozyme markers of competition in swards between short-leaved and long-leaved perennial ryegrass. Grass and Forage Science, 50, 241-248. https://doi.org/10.1111/j.1365-2494.1995.tb02319.x

Heap, I. M. (1997). The occurrence of herbicide-resistant weeds worldwide. Pesticide Science, 51, 235-243. https://doi.org/10.1002/ (SICI)1096-9063(199711)51:3\%3c235::AID-PS649\%3e3.0.CO;2-N

Heckman, J. R., Liu, H., Hill, W., DeMilia, M., \& Anastasia, W. L. (2000). Kentucky bluegrass responses to mowing practice and nitrogen fertility management. Journal of Sustainable Agriculture, 15, 25-33. https://doi.org/10.1300/J064v15n04_04

Hensler, K. L., Baldwin, B. S., \& Goatley, J. M. (2001). Comparing seeded organic-fiber mat with direct soil seeding for warm-season turfgrass establishment. HortTechnology, 11, 243-248. https://doi. org/10.21273/HORTTECH.11.2.243

Holt, J. S. (1995). Plant responses to light: A potential tool for weed management. Weed Science, 43, 474-482. https://doi.org/10.1017/ S0043174500081509

Horowitz, M., Regev, Y., \& Herzlinger, G. (1983). Solarization for weed control. Weed Science, 31, 170-179. https://doi.org/10.1017/ S0043174500068788

Hoyle, J. A., McElroy, J. S., \& Rose, J. J. (2012). Weed control using an enclosed thermal heating apparatus. Weed technology, 26, 699-707. https://doi.org/10.1614/WT-D-12-00057.1

Hubbard, M., Taylor, W. G., Bailey, K. L., \& Hynes, R. K. (2016). The dominant modes of action of macrocidins, bioherbicidal metabolites of Phoma macrostoma, differ between susceptible plant species. Environmental and Experimental Botany, 132, 80-91. https://doi.org/10.1016/j.envexpbot.2016.08.009

Hull, R. J. (2000). Mowing - Its impact on turfgrasses. Turfgrass Trends, 9, 1-8.

Hynes, R. K. (2018). Phoma macrostoma: As a broad spectrum bioherbicide for turf grass and agricultural applications. CAB Reviews, 13, 1-9. https://doi.org/10.1079/PAVSNNR201813005

Ikenaga, S., \& Inamura, T. (2008). Evaluation of site-specific management zones on a farm with 124 contiguous small paddy fields in a multiple-cropping system. Precision Agriculture, 9, 147-159. https://doi.org/10.1007/s11119-008-9062-4

Imaizumi, S., Nishino, T., Miyabe, K., Fujimori, T., \& Yamada, M. (1997). Biological control of annual bluegrass (Poa annua L.) with a Japanese isolate of Xanthomonas campestris pv. poae (JT-P482). Biological control, 8, 7-14. https://doi.org/10.1006/bcon.1996. 0475

Jabran, K., \& Farooq, M. (2013). Implications of potential allelopathic crops in agricultural systems. In Z. A. Cheema (Ed.), Allelopathy current trends and future applications (pp. 349-385). Basingstoke, UK: Springer Nature.

Jabran, K., Mahajan, G., Sardana, V., \& Chauhan, B. S. (2015). Allelopathy for weed control in agricultural systems. Crop Protection, 72, 57-65. https://doi.org/10.1016/j.cropro.2015.03.004

Jagschitz, J. A., \& Ebdon, J. S. (1985). Influence of mowing, fertilizer and herbicide on crabgrass infestation in red fescue turf. In F. Lemaire (Ed.), Proceedings of the 5th International Turfgrass
Research Conference, Avignon, France. 1-5 July 1985 (pp. 699-704). Paris: Institut national de la recherche agronomique.

Jeangros, B., \& Nösberger, J. (1990). Effects of an established sward of Lolium perenne L. on the growth and development of Rumex obtusifolius L. seedlings. Grass and Forage Science, 45, 1-7. https: //doi.org/10.1111/j.1365-2494.1990.tb02176.x

John, R. S., \& DeMuro, N. (2013). Efficacy of corn gluten meal for common dandelion and smooth crabgrass control compared to nitrogen fertilizers. Applied Turfgrass Science, 10, 1-8. https://doi. org/10.1094/ATS-2013-0426-01-RS

Johnson, B. J. (1981). Effect of herbicide and fertilizer treatments on weeds and quality of Kentucky bluegrass turf. In R. W. Sheard (Ed.), Proceedings of the 4th International Turfgrass Research Conference, Guelph, ON, Canada. 19-23 July 1981 (pp. 369-376). Guelph, ON, Canada: Ontario Agricultural College, University of Guelph \& International Turfgrass Society.

Johnson, B. J., \& Bowyer, T. H. (1982). Management of herbicide and fertility levels on weeds and Kentucky bluegrass turf. Agronomy Journal, 74, 845-850.

Johnson, C. K., Doran, J. W., Duke, H. R., Wienhold, B. J., Eskridge, K. M., \& Shanahan, J. F. (2001). Field-scale electrical conductivity mapping for delineating soil conditions. Soil Science Society of America Journal, 65, 1829-1837. https://doi.org/10.2136/sssaj2001. 1829

Johnson, D. R., Wyse, D. L., \& Jones, K. J. (1996). Controlling weeds with phytopathogenic bacteria. Weed Technology, 10, 621624. https://doi.org/10.1017/S0890037X00040549

Johnston, W., \& Golob, C. (2017). Biological control of Poa annua in fairways. Retrieved from http://turf.wsu.edu/wp-content/ uploads/2013/09/NTA-REPORT-Biocontrol-2017-FINAL.pdf

Juska, F. V., Tyson, J., \& Harrison, C. M. (1955). The competitive relationship of Merion bluegrass as influenced by various mixtures, cutting heights, and levels of nitrogen. Agronomy Journal, 47, 513518. https://doi.org/10.2134/agronj1955.00021962004700110006x

Karabelas, A. J., Plakas, K. V., Solomou, E. S., Drossou, V., \& Sarigiannis, D.A. (2009). Impact of European legislation on marketed pesticides-A view from the standpoint of health impact assessment studies. Environment International, 35, 1096-1107. https:// doi.org/10.1016/j.envint.2009.06.011

Kato-Noguchi, H. (2003). Isolation and identification of an allelopathic substance in Pisum sativum. Phytochemistry, 62, 1141-1144. https://doi.org/10.1016/S0031-9422(02)00673-8

Kay, S., \& Bonas, U. (2009). How Xanthomonas type III effectors manipulate the host plant. Current Opinion in Microbiology, 12, 3743. https://doi.org/10.1016/j.mib.2008.12.006

Kennedy, A. C. (2016). Pseudomonas fluorescens strains selectively suppress annual bluegrass (Poa annua L.). Biological Control, 103, 210-217. https://doi.org/10.1016/j.biocontrol.2016.09.012

Kirkland, K. J., \& Beckie, H. J. (1998). Contribution of nitrogen fertilizer placement to weed management in spring wheat (Titicum aestivum). Weed Technology, 12, 507-514. https://doi.org/10.1017/ S0890037X00044225

Knot, P., Hrabe, F., Hejduk, S., Skladanka, J., Kvasnovsky, M., Hodulikova, L., ... Horky, P. (2017). The impacts of different management practices on botanical composition, quality, colour and growth of urban lawns. Urban Forestry and Urban Greening, 26, 178-183. https://doi.org/10.1016/j.ufug.2017.01.011

Kristoffersen, P., Rask, A. M., \& Larsen, S. U. (2008). Non-chemical weed control on traffic islands: A comparison of the efficacy of 
five weed control techniques. Weed Research, 48, 124-130. https: //doi.org/10.1111/j.1365-3180.2007.00612.x

Krum, J. M., Carrow, R. N., \& Karnok, K. (2010). Spatial mapping of complex turfgrass sites: Site-specific management units and protocols. Crop Science, 50, 301-315. https://doi.org/10.2135/ cropsci2009.04.0173

Kuo, S. (1993a). Effect of lime and phosphate on the growth of annual bluegrass and creeping bentgrass in two acid soils. Soil Science, 156, 94-100. https://doi.org/10.1097/00010694-199308000-00005

Kuo, S. (1993b). Calcium and phosphorus influence creeping bentgrass and annual bluegrass growth in acidic soils. Horticultural Science, 28, 713-716.

Kuo, S., Brauen, S. E., \& Jellum, E. J. (1992). The effects of aluminum and phosphate on the growth of annual bluegrass and bentgrass in some acidic western Washington soils. Soil Science, 153, 365-372. https://doi.org/10.1097/00010694-199205000-00004

Larsen, S. U., \& Bibby, B. M. (2005). Differences in thermal time requirement for germination of three turfgrass species. Crop Science, 45, 2030-2037. https://doi.org/10.2135/cropsci2004.0731

Larsen, S. U., \& Fischer, J. (2005). Turfgrass management and weed control on golf course fairways without pesticides. International Turfgrass Society Research Journal, 10, 1213-1221.

Larsen, S. U., Kristoffersen, P., \& Fischer, J. (2004). Turfgrass management and weed control without pesticides on football pitches in Denmark. Pest Management Science, 60, 579-587. https://doi.org/ $10.1002 /$ ps.845

Latsch, R., Anken, T., Herzog, C., \& Sauter, J. (2017). Controlling Rumex obtusifolius by means of hot water. Weed Research, 57, 1624. https://doi.org/10.1111/wre.12233

Law, Q. D., Trappe, J. M., Jiang, Y., Turco, R. F., \& Patton, A. J. (2017). Turfgrass selection and grass clippings management influence soil carbon and nitrogen dynamics. Agronomy Journal, 109, 1719-1725. https://doi.org/10.2134/agronj2016.05.0307

Li, Y. Q., Sun, Z. L., Zhuang, X. F., Xu, L., Chen, S. F., \& Li, M. Z. (2003). Research progress on microbial herbicides. Crop Protection, 22, 247-252. https://doi.org/10.1016/S0261-2194(02)00189-8

Lipson, D. A., Raab, T. K., Schmidt, S. K., \& Monson, R. K. (2001). An empirical model of amino acid transformations in an alpine soil. Soil Biology and Biochemistry, 33, 189-198. https://doi.org/10.1016/ S0038-0717(00)00128-0

Lodge, T. A., \& Lawson, D. M. (1993). The construction, irrigation and fertiliser nutrition of golf greens. Botanical and soil chemical measurements over 3 years of differential treatment. Journal of the Sports Turf Research Institute, 69, 59-73.

Luu, K. T., Matches, A. G., \& Peters, E. J. (1982). Allelopathic effects of tall fescue on birdsfoot trefoil as influenced by $\mathrm{N}$ fertilization and seasonal changes. Agronomy Journal, 74, 805-808. https://doi. org/10.2134/agronj1982.00021962007400050009x

Lyons, E., Jordan, K., \& Carey, K. (2015). Evaluation of Fiesta and liquid corn gluten meal for pre-emergent control of turfgrass weedsGreenhouse and bare soil trial. Guelph, ON, Canada: Guelph Turfgrass Institute.

Macdonald, A. J., Powlson, D. S., Poulton, P. R., \& Jenkinson, D.S. (1989). Unused fertiliser nitrogen in arable soils-Its contribution to nitrate leaching. Journal of the Science of Food and Agriculture, 46, 407-419. https://doi.org/10.1002/jsfa.2740460404

Marble, S. C., Koeser, A. K., \& Hasing, G. (2015). A review of weed control practices in landscape planting beds: Part I-Nonchemical weed control methods. HortScience, 50, 851-856. https://doi.org/ 10.21273/HORTSCI.50.6.851

Marciano, P., Di Lenna, P., \& Magro, P. (1983). Oxalic acid, cell walldegrading enzymes and $\mathrm{pH}$ in pathogenesis and their significance in the virulence of two Sclerotinia sclerotiorum isolates on sunflower. Physiological Plant Pathology, 22, 339-345. https://doi.org/ 10.1016/S0048-4059(83)81021-2

Mashingaidze, A. B., Lotz, L. A., Van der Werf, W., Chipomho, J., Kropff, M. J., \& Nabwami, J. (2010). The influence of fertilizer placement on maize yield and growth of weeds. Proceedings of 2010 Jkuat Scientific Technological and Industrialization Conference, Nairobi, Kenya, 17-19 Nov. 2010 (pp 786-800). Nairobi: Jomo Kenyatta University of Agriculture and Technology

Masin, R., Zuin, M. C., Archer, D. W., Forcella, F., \& Zanin, G. (2005). WeedTurf: A predictive model to aid control of annual summer weeds in turf. Weed Science, 53, 193-201. https://doi.org/10.1614/ WS-04-066R1

Mathiassen, S. K., Bak, T., Christensen, S., \& Kudsk, P. (2006). The effect of laser treatment as a weed control method. Biosystems Engineering, 95, 497-505. https://doi.org/10.1016/j.biosystemseng. 2006.08.010

Mattner, S. W., \& Parbery, D. G. (2001). Rust enhanced allelopathy of perennial ryegrass against white clover. Agronomy Journal, 93, 54-59. https://doi.org/10.2134/agronj2001.93154x

May, J. H., Hall, J. R., Chalmers, D. R., \& Carry, P. R. (2009). Nutrient management for golf courses. Virginia Cooperative Extension Publications 430-399. Retrieved from https://www.pubs.ext. vt.edu/430/430-399/430-399.html

McCarty, L. B., Murphy, T.R., \& Turgeon, A. J. (1994). Control of turfgrass weeds. In A. J. Turgeon (Ed.), Turf weeds and their control (pp. 209-248). Madison, WI: ASA and CSSA.

McElroy, J. S., \& Martins, D. (2013). Use of herbicides on turfgrass. Planta Daninha, 31, 455-467. https://doi.org/10.1590/S010083582013000200024

McKernan, D. K., Ross, J. B., \& Tompkins, D. K. (2001). Evaluation of grasses grown under low maintenance conditions. International Turfgrass Society Research Journal, 9, 25-32.

McVey, G. R. (1968). How seedling respond to phosphorus. Weeds, Trees and Turf, 7, 18-19.

Murray, J. J., Klingman, D. L., Nash, R. G., \& Woolson, E. A. (1983). Eight years of herbicide and nitrogen fertilizer treatments on Kentucky bluegrass (Poa pratensis) turf. Weed Science, 31, 825-831. https://doi.org/10.1017/S0043174500070818

Nam-Il, P., Ogsasawara, M., Yoneyama, K., \& Takeuchi, Y. (2001). Responses of annual bluegrass (Poа апnиа L.) and creeping bentgrass (Agrostis palustris Huds.) seedlings to nitrogen, phosphorus and potassium. Weed Biology and Management, 1, 222-225. https: //doi.org/10.1046/j.1445-6664.2001.00038.x

Neumann, S., \& Boland, G. J. (1999). Influence of selected adjuvants on disease severity by Phoma herbarum on dandelion (Taraxacum officinale). Weed Technology, 13, 675-679. https://doi.org/10.1017/ S0890037X00042068

Niehaus, M. H. (1974). Effects of nitrogen fertilizer and mowing height on weed content of a Kentucky bluegrass turf. Research Summary 79. Wooster, OH: Ohio Agricultural Research and Development Center.

Nishino, J., \& Tateno, A. (2000). Camperico-A new bioherbicide for annual bluegrass in turf. Agrochemicals Japan, 77, 13-14. 
Norrington-Davies, J., \& Buckeridge, K. J. (1994). Plant interference and chemical toxins in upland pastures. Grass and Forage Science, 49, 176-182. https://doi.org/10.1111/j.1365-2494.1994.tb01990.x

Nyholt, A. (2010). Effects of long-term overseeding on fairway quality. (In Danish) Greenkeeperen, 2, 72.

O’Connor, K., Hébert, F., Powers, J. E., Jordan, K. S., \& Lyons, E. M. (2018). Leaf morphology explains the disparity between annual bluegrass and creeping bentgrass growth under foliar fertilization. Journal of Plant Nutrition, 41, 596-608. https://doi.org/10.1080/ 01904167.2017.1406109

PACE Turf (2014). Minimum levels for sustainable nutrition soil guidelines. Retrieved from https://www.paceturf.org/PTRI/ Documents/1202_ref.pdf

Parr, T. W. (1985). The control of weed populations during grass establishment by the manipulation of seed rates. In J. S. Brockman (Ed.), Weeds, pests and diseases of grassland and herbage legumes (pp. 20-28). Croydon, UK: British Crop Protection Council Publications.

Patton, A., \& Weisenberger, D. (2012). Evaluation of crabgrass control with various dimension formulations and corn gluten meal. 2011 Annual Report (pp. 31-32). West Lafayette, IN: Turfgrass Science Program, Purdue University.

Peters, E., \& Luu, K. T. (1985). Allelopathy in tall fescue. In A. C. Thompson (Ed.), The chemistry of allelopathy (pp. 273-283). Washington DC: American Chemical Society.

Peters, E. J., \& Mohammed Zam, A. H.B. (1981). Allelopathic effects of tall fescue genotypes. Agronomy Journal, 73, 56-58. https://doi org/10.2134/agronj1981.00021962007300010013X

Qian, Y. L., Bandaranayake, W., Parton, W. J., Mecham, B., Harivandi, M. A., \& Mosier, A. R. (2003). Long-term effects of clipping and nitrogen management in turfgrass on soil organic carbon and nitrogen dynamics. Journal of Environmental Quality, 32, 1694-1700. https://doi.org/10.2134/jeq2003.1694

Rajaniemi, T. K. (2002). Why does fertilization reduce plant species diversity? Testing three competition-based hypotheses. Journal of Ecology, 90, 316-324. https://doi.org/10.1046/j.1365-2745.2001. 00662.x

Rice, E. L. (1987). Allelopathy: An overview. In G. R. Waller (Ed.), Allelochemicals: Role in agriculture and forestry (pp. 8-22). Washington, DC: American Chemical Soc.

Riddle, G. E., Burpee, L. L., \& Boland, G. J. (1991). Virulence of Sclerotinia sclerotiorum and S. minor on dandelion (Taraxacum officinale). Weed Science, 39, 109-118. https://doi.org/10.1017/ S0043174500057969

Roux-Michollet, D., Czarnes, S., Adam, B., Berry, D., Commeaux, C., Guillaumaud, N., ... Clays-Josserand, A. (2008). Effects of steam disinfestation on community structure, abundance and activity of heterotrophic, denitrifying and nitrifying bacteria in an organic farming soil. Soil Biology and Biochemistry, 40, 1836-1845. https: //doi.org/10.1016/j.soilbio.2008.03.007

Schnick, P. J., \& Boland, G. J. (2004). 2, 4-D and Phoma herbarum to control dandelion (Taraxacum officinale). Weed Science, 52, 808814. https://doi.org/10.1614/WS-03-085R

Seigler, D.(2006). Basic pathways for the origin of allelopathic compounds. In M. Reigosa (Ed.), Allelopathy: A physiological process with ecological implications (pp. 11-61). Dordrecht, Netherlands: Springer.

Shaner, D. L., Khosla, R., Brodahl, M. K., Buchleiter, G. W., \& Farahani, H. J. (2008). How well does zone sampling based in soil elec- trical conductivity maps represent soil variability? Agronomy Journal, 100, 1472-1480. https://doi.org/10.2134/agronj2008.0060

Shearman, R. C., Steinegger, D. H., Kinbacher, E. J., \& Riordan, T. P. (1979). A comparison of turfgrass clippings, oat straw, and alfalfa as mulching material. Journal of the American Society for Horticultural Science, 104, 461-463.

Shepherd, M. A., Stockdale, E. A., Powlson, D. S., \& Jarvis, S. C. (1996). The influence of organic nitrogen mineralization on the management of agricultural systems in the UK. Soil Use and Management Journal, 12, 76-85. https://doi.org/10.1111/j.1475-2743.1996.tb00963. $\mathrm{X}$

Silvertown, J. (1987). Ecological stability: A test case. The American Naturalist, 130, 807-810. https://doi.org/10.1086/284748

Silvertown, J., Poulton, P., Johnston, E., Edwards, G., Heard, M., \& Biss, P. M. (2006). The park grass experiment 1856-2006: Its contribution to ecology. Journal of Ecology, 94, 801-814. https://doi. org/10.1111/j.1365-2745.2006.01145.x

Smith, J., Wherley, B., Baumann, P., Senseman, S., White, R., \& Falk, S. (2013). Early summer slender aster control in bermudagrass using bioherbicide Phoma macrostoma. Journal of Biofertilizers \& Biopesticides, 4(139), 2. https://doi.org/10.4172/2155-6202. 1000139

Smith, J., Wherley, B., Reynolds, C., White, R., Senseman, S., \& Falk, S. (2015). Weed control spectrum and turfgrass tolerance to bioherbicide Phoma macrostoma. International Journal of Pest Management, 61, 91-98.

Snaydon, R. W. (1971). An analysis of competition between plants of Trifolium repens collected from contrasting soils. Journal of Applied Ecology, 8, 687-697. https://doi.org/10.2307/2402677

Snaydon, R. W., \& Howe, C. D. (1986). Root and shoot competition between established ryegrass and invading grass seedlings. Journal of Applied Ecology, 23, 667-674. https://doi.org/10.2307/ 2404044

Sowers, R. S., \& Welterlen, M. S. (1988). Seasonal establishment of bermudagrass using plastic and straw mulches. Agronomy Journal, 80, 144-148. https://doi.org/10.2134/agronj1988.0002 $1962008000010031 \mathrm{x}$

Starr, J. L., \& DeRoo, H. C. (1981). The fate of nitrogen fertilizer applied to turfgrass. Crop Science, 21, 531-536. https://doi.org/10. 2135/cropsci1981.0011183X002100040014x

Stewart-Wade, S. M., Neumann, S., Collins, L. L., \& Boland, G. J. (2002). The biology of Canadian weeds. 117. Taraxacum officinale GH Weber ex Wiggers. Canadian Journal of Plant Science, 82, 825853. https://doi.org/10.4141/P01-010

Stoate, C., Baldi, A., Beja, P., Boatman, N. D., Herzon, I., van Doorn, A., ... Ramwell, C. (2009). Ecological impacts of early 21st century agricultural change in Europe-A review. Journal of Environmental Management, 91, 22-46. https://doi.org/10.1016/j.jenvman. 2009.07.005

Stowell, L., \& Gelernter, W. (2006). Sensing the future. Golf Course Management, 74, 107-110.

Templeton, W. C., \& Taylor, T. H. (1966). Yield response of a tall fescue-white clover sward to fertilization with nitrogen, phosphorus, and potassium. Agronomy Journal, 58, 319-322. https://doi. org/10.2134/agronj1966.00021962005800030022x

Thompson, D. C., Clarke, B. B., \& Heckman, J. R. (1995). Nitrogen form and rate of nitrogen and chloride application for the control of summer patch disease in Kentucky bluegrass. Plant Disease, 79, 51-56. https://doi.org/10.1094/PD-79-0051 
Tilman, E. A., Tilman, D., Crawley, M. J., \& Johnston, A. E. (1999). Biological weed control via nutrient competition: Potassium limitation of dandelions. Ecological Applications, 9, 103-111. https://doi.org/10.1890/1051-0761(1999)009\%5b0103:BWCV $\mathrm{NC} \% 5 \mathrm{~d} 2.0 . \mathrm{CO} ; 2$

Turner, F. A., \& Van Acker, R.C. (2014). Fertilizer application has no effect on large (Digitaria sanguinalis) or smooth (Digitaria ischaemum) crabgrass germination and emergence in residential turfgrass in a northern climate. Weed Science, 62, 145-157. https: //doi.org/10.1614/WS-D-13-00068.1

Unruh, J. B., Christians, N. E., \& Horner, H. T. (1997). Herbicidal effects of the dipeptide alanyl-alanine on perennial ryegrass. Crop Science, 37, 208-212. https://doi.org/10.2135/cropsci1997. 0011183X003700010035x

USEPA. (2014). Notice of pesticide registration. Retrieved from https://www.epa.gov/pesticide-registration/federal-register-andpesticide-registration-notices-pesticide-inert.

Vargas, J. M., \& Turgeon, A. J. (2004). Poa annua: Physiology, culture and control of annual bluegrass. Hoboken, NJ: John Wiley \& Sons.

Vikrant, P., Verma, K. K., Rajak, R. C., \& Pandey, A. K. (2006). Characterization of a phytotoxin from Phoma herbarum for management of Parthenium hysterophorus L. Journal of Phytopathology, 154, 461-468. https://doi.org/10.1111/j.1439-0434.2006.01129.x

Voigt, T. B., Fermanian, T. W., \& Haley, J. E. (2001). Influence of mowing and nitrogen fertility on tall fescue turf. International Turfgrass Society Research Journal, 9, 953-956.

Waddington, D. V., T.R., Turner, J.M., Duich, \& Moberg, E. L. (1978). Effect of fertilization on Penncross creeping bentgrass. Agronomy Journal, 70, 713-718. https://doi.org/10.2134/agronj 1978.00021962007000050005x

Watschke, T. L., Dernoeden, P. H., \& Shetlar, D. J. (1995). Managing turfgrass pests. London, U.K.: Lewis Publishers.

Watschke, T. L., \& Engel, R. E. (1994). Ecology of turfgrass weeds. In A. J. Turgeon (Ed.), Turf weeds and their control (pp. 29-36). Madison, WI: ASA and CSSA.

Watson, A. (2007). Sclerotinia minor-Biocontrol target or agent? In V. Maurizio \& G. Jonathan (Eds.), Novel biotechnologies for biocontrol agent enhancement and management (pp. 205-211). Dordrecht, Netherlands: Springer.

Webber, III, C. L., Harris, M. A., Sherefler, J. W., Durnova, M., \& Christopher, C. A. (2005). Vinegar as an organic burn-down her- bicide. In L. Brandenbarger (Ed.), Proceedings of the 24th Annual Horticulture Industries Show (pp. 168-172). Stillwater, OK: Oklahoma State University.

Webber, III, C. L., \& Shrefler, J. W. (2006). Vinegar as a burndown herbicide: Acetic acid concentrations, application volumes, and adjuvants. Retrieved from https://www.ars.usda.gov/ research/publications/publication/?seqNo115 $=195808$

Weed Science Scocity of America. (2017). Common and chemical names approved by the WSSA. Retrieved from http://wssa.net/ wssa/weed/herbicides/

Westwood, J. H., Charudattan, R., Duke, S. O., Fennimore, S.A., Marrone, P., Slaughter, D. C., ... Zollinger, R. (2018). Weed management in 2050: Perspectives on the future of weed science. Weed Science, 66, 275-285. https://doi.org/10.1017/wsc.2017.78

Woods, M., Stowell, L., \& Gelernter, W. (2014). Just what the grass requires: Using minimum levels for sustainable nutrition. Golf Course Management, January, 132-136.

Wu, L. X., Harivandi, M. A., \& Guo, X. (2002). Distribution of phenolic acids and allelopathic potential in cool-season and warm-season turfgrass species. California Turfgrass Culture, 52, 5-9.

Wymore, L.A., \& Lorbeer, J. W. (1987). Effect of cold treatment and drying on mycelial germination by sclerotia of Sclerotinia minor. Phytopathology, 77, 851-856. https://doi.org/10.1094/Phyto77-851

Zhou, T., \& Neal, J. C. (1995). Annual bluegrass (Poa annua) control with Xanthomonas campestris pv. poannua in New York State. Weed Technology, 9, 173-177. https://doi.org/10.1017/ S0890037X00023137

How to cite this article: Hahn D, Sallenave R, Pornaro C, Leinauer B. Managing cool-season turfgrass without herbicides: Optimizing maintenance practices to control weeds. Crop Science. 2020;1-17. https://doi.org/10.1002/csc2.20175 